\title{
Intentionality of Poetic Discourse
}

\author{
Liliia Bezugla \\ Department of German Philology and Translation, V. N. Karazin National University, Kharkiv, Ukraine \\ Viktoriia Ostapchenko \\ Department of Foreign Languages, O. M. Beketov National University of Urban Economy, Kharkiv, Ukraine
}

\begin{abstract}
This paper provides a new conception of analysing poetic text in terms of speech act theory proceeding from Searle's concept of intentionality, from Dijk's view on literary speech act based on the intention of the author and from Merilai's understanding of pragmapoetics. We argue that the author's intention in the poetic discourse comes in two varieties: the referential and the aesthetic ones. The referential intention is the author's attitude towards the text content. The aesthetic intention is the author's attitude towards the language form, through which the content is expressed. Thus, two kinds of speech acts are performed simultaneously: 1) referential, based on the referential intention, involving an illocution and being fictional, as the sincerity rule is violated; 2) aesthetic, based on the aesthetic intention. The latter is a specific subtype of expressive illocution as the author's illocutionary goal is to express a positive emotional-evaluative attitude solely toward the language form, while the perlocutionary goal is to influence the reader's aesthetic feelings regarding this form. These kinds of intention are reflected at both the level of the utterance and the whole text. Thus two communication levels are taken into consideration: the vertical and horizontal ones. The poetic texts of "New objectivity", a literary movement in German Weimar Republic in 1918-1933 have been used to observe these regularities.
\end{abstract}

Index Terms - aesthetic intention, aesthetic speech act, New objectivity, poetic discourse, pragmapoetics

\section{INTRODUCTION}

Since the ancient times, poetry has been one of the most appealing objects of linguistic analysis. Developing the traditional views on the poetic speech in stylistics and poetics, linguistics approbates new approaches, primarily the cognitive and the pragmatic ones.

The characteristic features of a poetic text, namely: aesthetics, emotiveness, fictionality, self-reference, iconicity, musicality, content capacity, nonlinearity and multiple interpretations are today considered in terms of cognitive approach with an emphasis on their mental base and the mechanisms of text production by the author as well as its perception by the interpreter. This contributes to the successful development of cognitive poetics.

The methods of linguistic pragmatics have turned to be not that simple to apply, so this has become a challenge for poetics in terms of the polarity of the research objects, namely: ordinary and literary speech. Nevertheless, there are steady processes of integration of these disciplines. In this regard, it is the cognitive methodology that provides new opportunities.

This paper deals with the theoretical issues concerning the integration of linguistic pragmatics, in particular the theory of speech acts, and linguistic poetics - the theory of poetic speech, based on the cognitive approach that considers the author's intention.

We present a concept of speech act analysis of the poetic text, based on the distinction between the two types of author's intention - the referential and the aesthetic ones.

We have developed this concept on the New Objectivity poetry texts (Neue Sachlichkeit) - a literary movement in German Weimar Republic in 1918-1933. We have analyzed the poetic texts by Joachim Ringelnatz (1883-1934), Erich Kästner (1899-1974) and Mascha Kaléko (1907-1975) - the representatives of the so-called utility poetry (Gebrauchslyrik), the value of which is seen in its easiness of perception and its usefulness for everyday life. Their poetic language is notable for its realism, simplicity, accuracy, laconicism, tradition of metrics and stanzas, lack of pathos and sensuality (Hillebrand 2011, p. 4). The New Objectivity aesthetics can be characterized by pragmatism, objectivity, documentarity, reportage style (Pankau, 2010, p. 8), which results in a relevant unambiguity and enables the speech act analysis.

After a short analytical review of the speech act analysis of literary discourse, we consider two types of intentions of the author of a poetic text - the referential and the aesthetic ones. Then we dwell on two speech act types in poetic discourse - the referential and the aesthetic ones, based on the two corresponding types of the author's intention. The closing section highlights the specifics of the felicity conditions of the aesthetic speech act.

\section{History OF SPEECH ACt ANALYSIS OF LiterARy DisCourSE}


Speaking about the history of the speech analysis of literary discourse, it is worth noting that it has not become widespread in linguistics. This is due to the opposite methodological attitudes of the corresponding linguistic disciplines - pragmatics and poetics.

While pragmatics deals with everyday communication, poetics focuses on the interpretation of literary texts. Both studying the language, these disciplines emphasize its various functions: pragmatics is interested in the communicative function of the language, while poetics focuses on the aesthetic/poetic function, as defined by Roman Jakobson (1981). Different functions of language in real-life communication and in poetry determine the difference in the correlations of content and form: in real-life communication it is the content that prevails, while in poetry it is form.

Nevertheless, despite the different methodological approaches, pragmatics and linguistic poetics have been demonstrating certain integrative processes since 1970s.

We can distinguish three main stages of pragmatics and poetics integration.

The 1970s introduced the analysis of the dialogues of fiction characters as samples of ordinary speech based on R. Ohman's concept of "hypothetical", "mimetic" or "quasi-speech-act" in the literary text (Ohman, 1971a, p. 254; 1971b, p. 17). Imitating the speech acts of the characters, the author shifts the reader's attention to the locutionary acts themselves, since the language of the stylized colloquial speech accurately reflects the features of live speech.

In the 1980-1990s pragmatic linguists of the Federal Republic of Germany unfold a polemic about the possibility of using fiction dialogues for speech act analysis. This polemic resulted in a very significant conclusion that there are two types (levels, aspects) of communication in literary discourse: internal/horizontal (communication of characters with each other) and external/vertical (communication between the author and the reader) (Betten, 1986, p. 8).

At the same time, in the 1980s the focus of attention shifted from the literary text to the process of literary communication. The concept of the author's intention was formulated and came into the fore (Dijk, 1980; Searle 1979).

J. R. Searle emphasized the necessity to develop a theory that would allow for analyzing serious speech acts of the author of the literary text performed through pretended illocutions (1979, p. 75).

Within an integrated theory of literature and discourse, T. van Dijk (1979) described the features of written communication in terms of cognitive processes that define the understanding/interpretation of discourse. He refered to literary speech acts as "impressive" or "ritual", as they are based on the author's intention to change the attitude of the hearer with respect to the context in the socio-cultural interaction (Dijk, 1980, p. 9). He states that "the pragmatic analysis of literature is just beginning" (Dijk, 1980, p. 16).

Finally, in the XXI century an Estonian scholar Arne Merilai (2007) develops Jakobson's concept of self-reference and introduces the term "pragmatic poetics".

Merilai (2007) analyses poetic texts and reduces the six Jakobson's functions of language to two ones: emotive and referential, while conative functions are viewed as belonging to referential, and poetic, phatic and metalingual - to selfreferential (p. 382). He considers the self-referential function in the poetic text as primary one:

The most essential property of the art of poetry is certainly its posing the self-referential function as primary, while the mimetic activity or the referential function recedes to a secondary position. Literature boosts linguistic self-referentiality that is relatively covert in ordinary speech, and turns the seemingly or actually referring utterances into an aim in itself, e.g. often shifting the attention from the content of the expression to the linguistic nature of the expressions themselves (Merilai, 2007, p. 383).

Merilai (2007) concludes that poetic utterances as a specific way of language usage realise not one but two speech acts: a referential and a self-referential one. These speech acts correspond to the two contexts of the poetic text: 1) the narrow context, or the aspect of the content and reference; 2) the broad context, or the aspect of the expression and selfreference. While the narrow context involves an implied author, fiction, internal content and form, imagined reference and virtual/non-virtual speech acts; the broad context provides a real author, actuality, external/expressive content and form, self-referentiality as well as actual or "self-defeating" speech acts (Merilai, 2007, p. 386). Therefore, in single utterances there are two levels of perception, of meaning and force:

So, the actual content of a poem is not, or is not only, its particular content (as a string of the propositions or their summary), but rather the way this content is linguistically presented, its form and style. Expression itself becomes a content (Merilai, 2007, p. 389).

The theory of two contexts finds a successful explanation for the combination of fictional and communicative principles in the poetic text. Fictionality concerns the narrow context; it does not have to coincide with reality, while communication deals with the broad context as it is oriented to the prospect of the author communicating with the reader through the text as a work of art.

Developing the model of the two contexts of literary perception, we must admit that the analysis of the context is text-centred. However, modern pragmatics with its cognitive and discursive approach is subject-centred. Subjectcentred analysis of the pragmatics of poetic discourse is possible in terms of intentional approach.

In addition to the two types of context in the linguistic pragmatic analysis of poetic discourse, we should take into account two types of communication inherent to the narrow context: the horizontal and the vertical ones. Otherwise, the analysis of conversational discourse (within the subject-centred approach) and the interpretation of the text (which can be subject- centred or text-centred) can be confused. 
Thus, the presented concept of poetic text analysis from the perspective of speech act theory elaborates on Dijk's thesis on literary speech act resting on the author's intention, on Merilai's pragmatic poetics and on Searle's intentionality concept.

\section{Two Kinds of Author's InTEntion In the PoEtic Discourse}

We argue that there are two kinds of author's intention in the poetic discourse.

The notion of intention belongs to cognitive psychology. Searle (1983) defines it as follows:

Intentionality is that property of many mental states and events by which they are directed at or about or of objects and states of affairs in the world (p. 1).

Searle (1983) gives examples of intentional states: belief, hope, desire, love, hate, liking, disliking, doubting, wondering whether, joy, pride, sorrow, guilt, wishing, wanting etc. (p. 1f.). He compares pain and hope. Pain is nonintentional because an utterance about it only describes it. On the contrary, expressing hope implies the necessity of clarifying the focus of these states: What does the person hope for? Indeed, one cannot hope unless one is aware what to hope for. In other words, the state of intention always involves a certain object.

According to Lapp (1992), depending on the leading mental component, intentions fall into the following categories: 1) cognitive (knowledge, ignorance, doubt, assumption, faith, confidence, rational assessment), 2) volitive (hope, desire, intention) and 3) affective (emotional assessment, attitude towards the addressee, emotions) (p. 137).

Considering the intentional approach in the poetic text analysis, we suggest to consider another subtype among affective intentions - the aesthetic intention, which is the author's mental direction at the created word form with a positive emotional-evaluative attitude towards it.

The key point in this definition is the phrase "verbal form". It is the form, not the content, that evokes the author's positive emotional and evaluative attitude - excitement, delight, joy etc., although his or her attitude to the content can be extremely negative. The author tries to convey the beauty of the verbal form to the reader of the text. The author seems to say to the reader: "Look what a harmonious text, what beautiful combinations of words and patterns of meanings!" If he/she considers the poem complete, then he/she is obviously pleased with the way the content is expressed (whatever it may be) while another subject (reader or critic) may not like the text, created by the author's aesthetic intention.

Searle (1983) distinguished two levels of intention. He wrote:

We need to have a clear distinction between representation and communication. Characteristically a man who makes a statement both intends to represent some fact or state of affairs and intends to communicate this representation to his hearers. But his representing intention is not the same as his communication intention. $<\ldots>$ There are, therefore, two aspects of meaning intentions, the intention to present and the intention to communicate. $\langle\ldots\rangle$ representation is prior to communication and representing intentions are prior to communication intentions. $\langle\ldots\rangle$ One can intend to represent without intending to communicate, but one cannot intent to communicate without intending to represent (p.165f.).

The first order intention (intention to present, or representing intention) represents how mental states are directed at objects and states of affairs in the world. The second order intention (intention to communicate, or communication intention) suggests the speaker's wish to render his or her representing intention to the addressee and trigger a certain reaction, i.e. perform a speech act.

The representing intention can exist without the communication intention, but the former is a prerequisite for the emergence of the latter. With the communication intention, the subject enters speech communication and becomes the speaker - the addresser.

The aesthetic intention of the author of a poetic text can exist only at the representational level - when the author writes a piece not for publication. However, as soon as he/she decides to publish the poems or speak with them to the audience, that is the text receives the addressee, the author becomes the addresser and his or her aesthetic intention turns from representing to communicative, resulting in the poetic discourse.

So, as we have previously concluded, in a poetic text, the author can express:

a) content, by correlating words with the states of affairs in the external world, i.e. making reference per se;

b) his or her attitude toward this content, i.e. the referential intention;

c) his or her attitude toward the language form, through which the content is expressed, referring utterances to themselves or making self-reference, that is the aesthetic intention (Bezugla, 2020, p. 23).

\section{Two Speech Act Types In THe Poetic Discourse}

Two types of author's intention cause two corresponding types of speech acts performed by the author through a poetic utterance/text.

This brought us to the conclusion that two kinds of speech acts are performed simultaneously:

1) referential speech act, based on the reference per se and the referential intention, involving an illocution and being fictional, as the sincerity rule is violated; 
2) aesthetic (self-referential) speech act, based on the self-reference and the aesthetic intention (Bezugla, 2020, p. 24).

Let us consider a miniature text “About murder and deathblow” by Erich Kästner (2004, p. 26):

Erich Kästner

VON MORD UND TOTSCHLAG

Denkt ans fünfte Gebot:

Schlagt eure Zeit nicht tot!

With the help of this text the author realizes his volitive intention and the directive speech act - a piece of advice.

The content of the advice is expressed in the implicature, the trigger of which is the phraseological phrase die Zeit totschlagen. Its inner form comes to life due to the expression das fünfte Gebot, which activates in the reader's mind the presuppositional knowledge of the content of the fifth commandment of Jesus Christ: +> „Du sollst nicht töten!" (,,Thou shalt not kill!") +> Zeitverschwenden ist ein Verstoß gegen das fünfte Gebot (Wasting time means breaking the fifth commandment). Hence, the author advises the reader not to waste his time: $+>$ Verschwendet nicht eure Zeit!

This stylistic device, as well as rhyme, metrics and stanza express the author's aesthetic intention, it is due to them that the aesthetic speech act is realised.

Thus, the poetic text demonstrates two speech acts - the referential directive and the aesthetic speech acts, which are based on the corresponding author's intentions - the referential and the aesthetic ones, and two text illocutions - a piece of advice and delight from the words expressing this advice.

This is an example of a transient analysis at the level of vertical communication between the author and the reader.

Speech act analysis can be also carried out at the level of horizontal communication between characters (if they are present in the text). Horizontal communication is subordinate to the vertical one, since the author uses it to convey a certain meaning. The analysis reaches the interdiscursive level, drawing on the conversational discourse integrated into the poetic discourse. An example here is the poetic text "A Little Difference" by Masha Kaléko (2012, p. 665):

Mascha Kaléko

DER KLEINE UNTERSCHIED

Es sprach zum Mister Goodwill

ein deutscher Emigrant:

„Gewiß, es bleibt dasselbe,

sag ich nun land statt Land,

sag ich für Heimat homeland

und poem für Gedicht.

Gewiss, ich bin sehr happy:

Doch glücklich bin ich nicht.“

The German emigrant performs the assertive speech acts - statements, conveying the implicature that he is unhappy in emigration: +> Weil ich nicht in meiner Heimat bin. But at the level of vertical communication, the author conveys a different implicature to the reader: +> Der Unterschied zwischen happy und glücklich ist in Wirklichkeit sehr groß, denn glücklich kann man nur im Heimatland sein (The difference between the words glücklich and happy is really great, since you can only be happy in your home country).

The aesthetic speech act demonstrates that the author tries to convey this idea to the reader in an original poetic form, using poetic means and attracting the reader's attention to them. If the author had not realised the aesthetic speech act, he would have simply expressed this idea in prose.

The aesthetic intention involves two sublevels in vertical communication of the poetic discourse - the content and the aesthetic ones. The substantial vertical communication (as well as horizontal) is based on reference per se and the author's referential intention. The aesthetic communication rests on self-reference and the author's aesthetic intention.

Aesthetic communication is clearly manifested in the verses where the author emphasizes the poetic form. For example, J. Ringelnatz's "Poem in Bi-language" (1928, p. 99) is at first glance nonsense:

Joachim Ringelnatz

GEDICHT IN BI-SPRACHE

Ibich habibebi dibich,

Lobittebi, sobi liebib.

Habist aubich dubi mibich

Liebib? Neibin, vebirgibib.

Nabih obidebir febirn,

Gobitt seibi dibir gubit.

Meibin Hebirz habit gebirn

Abin dibir gebirubiht.

This is nothing but a word play - inside each syllable, the author adds the syllable bi, encoding the message Ich habe dich, / Lotte, so lieb. / Hast auch du mich / Lieb? Nein, vergib. / Nah oder fern, / Gott sei dir gut. / Mein Herz hat gern / 
An dir geruht. This resembles a counting rhyme where the content is nothing but the material for the word form. Both the author's and the reader's focus falls on this word play, which is the aesthetic speech act.

Therefore, the conversation of the lyrical I with Lotte - the declaration of love, the question, the negative answer, the apology, the wishes and the statement (referential speech acts) - are not taken seriously.

This shows that the author's referential and aesthetic intentions can be expressed at both the level of the utterance and the whole text.

\section{Felicity Conditions of Aesthetic SpeECH Acts}

Defining the essence of any type of speech act involves considering the felicity conditions (Searle, 1969, p. $57 \mathrm{ff}$.). Therefore, we should dwell on the specifics of the felicity conditions for the aesthetic speech act.

The input and output condition of the aesthetic speech act is that the addresser and the addressee speak the same language, act consciously, voluntarily, not forcibly and not under threat, have no physical or mental obstacles, are in their right mind and sober memory, are not playing a role or sleeping.

It is impossible to engage in verbal creativity without speaking a certain language, being in an unconscious state, having mental disorders, being in the state of strong alcohol intoxication, imitating creativity on stage, in delirium or in a dream.

However, it should be noted here that inspiration is considered as an altered state of mind, which has led to the development of methods of composing poetry in an altered mental state (so-called psychedelic poetry). Some poets achieve this state under the influence of alcohol or drugs. However, these aspects of creative activity require special psycholinguistic studies.

In addition, this condition does not include jokes, which do not involve the realisation of the aesthetic speech act, as the incongruence in the verbal form can cause a positive emotional assessment and become the object of the aesthetic intention, as in "Poem in Bi-language" by J. Ringelnatz.

The addressee of the aesthetic speech act (the potential reader of the text) is a multiple, inhomogeneous addressee who is remote in time and space, and meets these conditions.

The preparatory condition in aesthetic speech acts is that both the author and the addressee must need poetry and be able to get aesthetic pleasure from it. N. Alefirenko and I. Chumak-Zhun (2008) found a good term for this category of people-Homo poeticus (p. 69). By realizing the aesthetic speech act, the Homo poeticus author tries to convey to the reader the beauty of word form. Nevertheless, if the reader is not a Homo poeticus, that is, does not see (or does not want to see) the word aesthetics, such speech act is considered "self-defeating".

The condition of propositional content stipulates that an aesthetic speech act can have any proposition, as well as a set of interrelated propositions at the text level. This means that the object of the aesthetic intention can be a mental projection of any verbal form.

The sincerity condition in aesthetic speech acts suggests that the author should really feel a positive emotional and evaluative attitude to the created verbal form and not falsify it.

The essential condition determines the communicative and intentional specifics of the illocution, that is, the speaker's illocutionary goal.

Aesthetic speech acts also have the aesthetic intention, which correlates with the emotive illocution. Aesthetic speech acts belong to the expressive type or emotive illocutionary type in particular.

We also distinguish the perlocution condition which determines the perlocutionary goal of the addresser associated with the illocution drawing from Cohen's associated and non-associated perlocutions (1973, p. $496 \mathrm{ff}$.).

The perlocutionary goal of the author of a poetic utterance is to influence the reader's aesthetic feelings regarding the word form.

Unlike the aesthetic speech act, the referential speech act in the poetic discourse is specific only in the sincerity condition: the author's sincerity is conditional, that is, he/she does not have to actually feel certain feelings or have certain views, while the described events and facts are true.

The inconsistency of word and reality is the basis of the poetic discourse fictionality. Therefore, poetics uses the term "lyrical I" - fictional double of the author-poet who may completely coincide with his/her personality, and may be completely different from it (Lamping, 1993, p. 61). M. Kaléko’s poems “A Little Difference” and Erich Kästner's "Murder and Death Strike" are examples of the lyrical I's coincidence with the author's self. J. Ringelnatz's "Poem in Bi-language" reflects the lyrical I's fictional humorous conversation with his beloved.

\section{CONCLUSIONS}

The intentional approach allows to identify the specifics of the analysis of the poetic discourse in terms of the speech act theory.

In the poetic discourse, we should consider two types of the author's intention and two types of speech acts, which are simultaneously realised in the poetic utterance and/or text, namely:

a) referential and aesthetic author's intentions,

b) corresponding referential and aesthetic (self-referential) speech acts. 
Two communication levels of the text are taken into consideration: the vertical and the horizontal ones.

The author's aesthetic intention enables communication with the reader of a poetic text, hence the poetic discourse.

Within the intentional approach to speech act analysis of the poetic discourse, pragmatic poetics becomes a cognitive discipline. Cognitive pragmatic poetics explores the ontology of poetic utterances as a specific way of language usage and concerns the activity of the human mind during the literary communication.

Speech act analysis in cognitive pragmatic poetics perspective is promising as it provides the view into the nature of pragmatic features of the poetic discourse of individual authors, as well as literary movements and genres.

\section{REFERENCES}

[1] Alefirenko, N. F., \& Chumak-Zhun, I. I. (2008). Kommunikativnaja situatsija kak kognitivno-pragmaticheskij faktor porozhdenija poeticheskogo diskursa [Communication situation as a cognitive and pragmatic factor of poetic discourse generation]. Auspisia. Recenzovan neimpaktovan asopis zamen na oblast spoleenskh vd. eske Budjovice: Vysok kola evropskch a regionlnch studi, 1, 68-73 [in Russian].

[2] Bezugla, L. (2020). Intentionality of poetic discourse. In P. Cap (Ed.) Book of Abstracts. 9th Lodz Symposium New Developments in Linguistic Pragmatics 11-12 May 2020. (pp. 23-24). Łódź: University of Łódź Press.

[3] Betten, A. (1986). Einige grundsätzliche Überlegungen zur Beschreibung alltagssprachlicher und literarischer Dialoge. In R. Hundsnurscher, \& E. Weigand (Eds.) Dialoganalyse (pp. 3-12). Tübingen: Niemeyer.

[4] Cohen, T. (1973). Illocutions und Perlocutions. Foundations of language, 9. 492-503.

[5] Dijk, T. van (1979). Cognitive processing of literary discourse. Poetics Today 1, 143-160.

[6] Dijk, T. van (1980). The pragmatics of literary communication. In E. Forastieri-Braschi, G. Guinness, \& H. Lopez-Morales (Eds.) On text and context (pp. 3-16). Rio Piedras, Puerto Rico: Editorial Universitaria.

[7] Hillebrand, R. (2011). Liebeslyrik der Neuen Sachlichkeit. München: GRIN.

[8] Jakobson, R. (1981). Linguistics and Poetics. In Roman Jakobson. Selected writings. 3: Poetry of Grammar and Grammar of Poetry (pp. 18-51). Paris/New York.

[9] Kaléko, Mascha. (2012). Sämtliche Werke und Briefe in vier Bänden. Herausgegeben und kommentiert von Jutta Rosenkranz. München: dtv.

[10] Kästner, Erich. (2004). Kurz und bündig. Epigramme. München: dtv.

[11] Lamping, D. (1993). Das lyrische Gedicht. Definitionen zu Theorie und Geschichte der Gattung. Göttingen: Vandenhoeck\&Ruprecht.

[12] Lapp, E. (1992). Linguistik der Ironie. Tübingen: Narr.

[13] Merilai, A. (2007). Pragmapoetics as literary philosophy. Interlitteraria 12, 379-392.

[14] Ohmann, R. M. (1971a). Speech, Action, and Style. In S. Chatman (Ed.) Literary Style: A Symposium (pp. 241-259). London: Oxford Univ. Press.

[15] Ohmann, R. M. (1971b). Speech Acts and the Definition of Literature. Philosophy and Rhetoric, 4, 14-19.

[16] Pankau, J. G. (2010). Einführung in die Literatur der Neuen Sachlichkeit. Darmstadt: WBG.

[17] Ringelnatz, Joachim. (1928). Allerdings. Berlin: Rowohlt.

[18] Searle, J. R. (1969). Speech Acts. Cambridge: Cambridge Univ. Press.

[19] Searle, J. R. (1979). The logical status of fictional discourse. In J. R. Searle. Expression and Meaning (pp. 58-75). Cambridge: Cambridge Univ. Press.

[20] Searle, J. R. (1983). Intentionality: An Essay in the Philosophy of Mind. Cambridge: Cambridge Univ. Press.

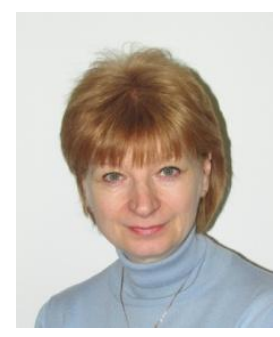

Liliia Bezugla born in Ukraine in 1963, in 1987 graduated from Kharkiv University (German Language Department), in 1992 - from English Language Department, earned the candidate degree (PhD) in Germanic Studies from the University of Kharkiv, Ukraine in 1998, got her doctoral degree (Doctor of Science) in Germanic Studies from Taras Shevchenko National University of Kyiv, Ukraine in 2009.

She started her career as a schoolteacher in Kharkiv, in 1992-1999 worked as a lecturer at the Department of Foreign Languages of Kharkiv Academy of Urban Economy, was promoted to Associate Professor at Kharkiv University at the Department of German Philology and Translation, was promoted to Professor in 2011 and is still working at this position at the same University. She has published about 200 articles in linguistics and translation. Her research interests are linguistic pragmatics, cognitive linguistics, discourse studies, linguistic poetics, translation studies, historical linguistics, and teaching German as a foreign language.

Prof. Bezugla is a member of Association of Ukrainian Germanists.

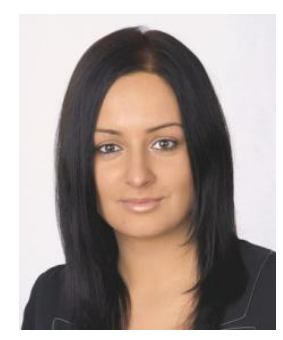

Viktoriia Ostapchenko born in Kharkiv (Ukraine) in 1989, in 2011 graduated from V.N. Karazin Kharkiv National University (qualifications: philologist, teacher of English language and literature, German language, translator), did her PhD in Philological Sciences at V.N. Karazin Kharkiv National University, Kharkiv, Ukraine in 2019.

She is a lecturer at the Department of Foreign Languages at O.M. Beketov National University of Urban Economy, Kharkiv, Ukraine since 2011. Her research interests are linguistic poetics, linguistic pragmatics, discourse analysis.

Ms. Ostapchenko has been a member of the International Professional Association of Teachers of English TESOL-Ukraine since 2012. 